\title{
Recent Developments in Antipoverty Policies in the United States
}

\author{
James P. Ziliak \\ Department of Economics \\ Center for Poverty Research \\ University of Kentucky
}

\section{Preferred citation}

Ziliak, James P. (September, 2011). Recent Developments in Antipoverty Policies in the United States. University of Kentucky Center for Poverty Research Discussion Paper Series, DP2011-05. Retrieved [Date] from http://www.ukcpr.org/Publications/DP2011-05.pdf.

Author correspondence

James P. Ziliak, Department of Economics, University of Kentucky, Lexington, KY 40506-0034. E-mail: jziliak@uky.edu. Phone: 859-257-2776.

University of Kentucky Center for Poverty Research, 302D Mathews Building, Lexington, KY, 40506-0047 Phone: 859-257-7641; Fax: 859-257-6959; E-mail: mary.boulton@uky.edu 


\title{
Recent Developments in Antipoverty Policies in the United States
}

\author{
James P. Ziliak \\ Center for Poverty Research \\ and \\ Department of Economics \\ University of Kentucky \\ jziliak@uky.edu
}

Revised September 2011

*Prepared for the East-West Center and Korea Development Institute Conference on Social Welfare Issues, August 18-19, 2011. I thank Tim Halliday and Karl Scholz for helpful comments on an earlier version, as well as seminar participants at the Tax Economists Forum in Washington, DC. All errors are my own. 


\begin{abstract}
I survey recent developments in antipoverty policy in the United States over the past decade and examine how the safety net and tax system affects poverty and its correlates using data from the 2000 to 2010 waves of the Current Population Survey-Annual Social and Economic Supplement. Unlike the 1980s and 1990s, and until the health care overhaul in 2009, the first decade of the $21^{\text {st }}$ Century was relatively tepid in terms of major transfer policy reforms. However, real spending on most major social program increased significantly, and in some cases doubled or tripled, in response to demographic shifts and the deep recession. In spite of the real growth in social insurance and means-tested transfer programs, the trends in after-tax and transfer poverty rates were little affected, and if anything, suggest the safety net has lost some of its antipoverty bite in terms of alleviating hardship among those living in deep poverty.
\end{abstract}

Keywords: Safety net, poverty, inequality, volatility 
The reach of antipoverty policy in the United States is vast, ranging from explicit income maintenance payments to implicit insurance via the tax code that smoothes income and consumption changes across people and over time (Kniesner and Ziliak 2002). However, how, and for whom, to provide support continues to be the subject of vigorous debate (Moffitt 2003; Currie 2006; Murray 2006; Haskins and Sawhill 2009; Heinrich and Scholz 2009; Ziliak 2009). While much reform effort in recent decades has been directed to making the safety net more work-based, especially the 1990s welfare reforms and expansions in the Earned Income Tax Credit, concurrently there has been a silent epidemic of disability insurance claims and awards that has been associated with a substantial decline in employment among the low-skilled (Autor and Duggan 2006; 2010). In this paper I discuss some recent developments in antipoverty policy and the association of these changes on the extent and distribution of poverty and its correlates.

The safety net in the U.S. is typically grouped into the two broad categories of social insurance and means tested transfers. As a general rule, social insurance programs are tied to employment or old age, while means tested transfers are not. Included in the former are Social Security Retirement and Survivors Benefits, Disability Insurance (DI), Medicare, Unemployment Insurance (UI), and Workers Compensation. Among the latter are Medicaid, Supplemental Security Income (SSI), Temporary Assistance for Needy Families (TANF), housing assistance, and the Supplemental Nutrition Assistance Program (SNAP). This list is not exhaustive, but does encompass the large majority of outlays. The other key means-tested program that is directly tied to employment is the Earned Income Tax Credit (EITC).

[Table 1 here] 
Table 1 contains expenditures on these programs for 1999 and 2009, the most recent year where data is widely available across programs. The values are reported in real 2010 dollars using the personal consumption expenditure deflator. Over the past decade, real spending on UI increased 370 percent, SNAP rose by 140 percent, Medicare increased 92 percent, DI rose by 86 percent, Medicaid increased 51 percent, the EITC by 48 percent, Social Security retirement and survivors by 34 percent, and SSI by 21 percent. Real spending on TANF was flat, while that of workers comp and housing assistance rose a modest 7 and 14 percent, respectively. While some predicted the demise of the welfare state with the passage of welfare reform in 1996, Table 1 makes clear that the past decade has witnessed real growth in all programs save cash welfare. What accounts for this spending boom in the safety net? The answer varies widely across programs, but typically can be accounted for by changing demographics, business cycles, policy implementation, and in some cases, policy reform.

I provide a brief overview of the major programs in the social safety net, and in the process describe the target populations and basic programmatic rules, along with recent reforms to benefit eligibility and generosity to assist the disadvantaged. I next use data from the March Current Population Survey from 2000 to 2010 to examine how the panoply of programs in the safety net ameliorates income poverty, inequality, and volatility. Specifically I construct three definitions of income: one that is restricted to private income sources; a second that adds cash transfer payments to private incomes (this is the official definition used by the Census Bureau to measure poverty); and a third that adds to the official Census income definition net capital gains, in-kind transfers, and net tax payments (i.e. the sum of federal, state, and payroll taxes inclusive of the refundable EITC). With the three income measures I assess the extent to which poverty rates are reduced by the safety net. 
Because most transfer programs do not have the explicit goal of eliminating poverty, rather the more modest objective of ameliorating income shortfalls, the poverty rate will not capture improvements among those persons living far below the poverty line. Hence I estimate how the safety net reduces the so-called aggregate poverty gap, which is the amount of money required to lift all persons up to the poverty line (Ziliak 2006; Ben-Shalom, Moffitt, and Scholz 2011). I complement this analysis with an assessment of how the safety net affects the distribution of income for the population overall as well as for the subpopulation of persons living in poverty. Moreover, I examine how much the safety net smoothes idiosyncratic income changes over time by matching individuals across subsequent waves of the March CPS. Together the descriptive analysis sheds light on how changes in safety net spending have affected the level, intensity, and inequality of poverty.

\section{Recent Changes in U.S. Antipoverty Policy}

Few would argue that changes in the U.S. social policy landscape in the 1980s and 1990s were nothing short of epochal. They altered significantly the economic rewards to work and to participation in transfer programs, and affected all segments of the low-income population. Perhaps no other demographic group was singled out by policy as prominently as single mothers with dependent children. President Reagan set in motion the retrenchment of the cash welfare program Aid to Families with Dependent Children (AFDC) by increasing the implicit tax rate on earnings and reducing the liquid asset level necessary to qualify for benefits as part of Omnibus Budget Reconciliation Act (OBRA) of 1981. This retrenchment was completed by President Clinton with passage of the 1996 Personal Responsibility and Work Opportunity Reconciliation Act, which abolished AFDC and replaced it with the new time-limited, block-grant program Temporary Assistance to Needy Families (TANF). Concurrent to restrictions to cash welfare 
were enhanced incentives for single mothers to work via expansions in the Earned Income Tax Credit (EITC) as part of the Tax Reform Act of 1986 and OBRA 1990 and 1993, as well as expansions in Medicaid program eligibility and later the introduction of the Supplemental Children’s Health Insurance Program as part of OBRA 1997. In 1991 Congress was required to modify rules for child eligibility in the Supplemental Security Income (SSI) program in light of the Supreme Court's 1990 Zebley decision that ruled unconstitutional previous guidelines. The revised rules resulted in a large increase in children participating in SSI, including many from single mother families on the AFDC program (Kubik 1999; Schmidt and Sevak 2004). The reforms to anti-poverty policy at the end of the $20^{\text {th }}$ Century have been studied extensively elsewhere (Bane and Ellwood 1996; Blank 1997; Moffitt 2003; Grogger and Karoly 2005; Haskins 2007; Ziliak 2009). I take these reforms as the starting point in this chapter and instead focus on changes to the safety net over the past decade.

\section{Social Insurance}

The growth in Social Security Retirement and Survivors Benefits from $\$ 424$ billion in 1999 to $\$ 568$ billion in 2009 is primarily a consequence of the demographic aging of the labor force into retirement years. The program is targeted to workers age 62 and older who have accumulated at least 40 quarters of covered employment in their careers, and benefits are paid out as a progressive function of pre-retirement earnings, i.e. low-wage workers receive a higher proportion of pre-retirement earnings paid out as benefits during retirement. Retirement benefits in 2008 provided 90 percent or more of income for nearly one-third of all beneficiaries, and over half of income for two-thirds of retirees, thus making it the single, largest anti-poverty program. ${ }^{1}$

\footnotetext{
${ }^{1}$ http://www.socialsecurity.gov/policy/docs/chartbooks/fast_facts/2010/fast_facts10.pdf
} 
Little has changed in terms of retirement program benefit structure since the Greenspan Commission of 1983. The most substantive legislative change in the past decade was the elimination of the retirement earnings test in 2000 for those persons who receive benefits starting at normal retirement age and yet to continue to work in the paid labor force. ${ }^{2}$ Specifically, for those retirees age 65 and older who continue to receive wage income, benefits are no longer reduced because of those earnings. Perhaps surprising in light of the current labor market, this change came about in part because of a shortage of skilled labor at the end of the high pressure 1990s economic expansion (Krueger and Solow 2001). But because relatively few seniors work beyond age 65, this reform likely introduced minimal upward pressure on outlays. The other change to retirement benefits this decade was the one-time payment of \$250 in 2009 to recipients as part of the American Recovery and Reinvestment Act (ARRA).

Like Social Security, the increase in Medicare spending is largely reflective of the aging population. Primary eligibility commences at age 65 for those qualifying for monthly Social Security Retirement Benefits, and with the growth in the latter Medicare spending has increased in lockstep. However, there are additional forces at work that has led to outlays in Medicare nearly doubling and catching up to those of retirement benefits. First, medical care inflation has exceeded overall inflation by nearly double over the past decade, thus driving up real costs. Second, recipients of DI are often eligible for Medicare after five months, and with the growth of disability, more Americans under age 65 are receiving Medicare coverage. Third, in 2004, President Bush signed into law a major expansion of Medicare benefits known as Part D, or the prescription drug benefit, that covers prescription costs not otherwise covered by Parts A and B

\footnotetext{
${ }^{2}$ http://www.ssa.gov/history/briefhistory3.html
} 
of Medicare. Participation in Part D is voluntary, and requires payment of a monthly premium, but that cost is either waived or heavily subsidized for low-income retirees.

Disability insurance was added to the Social Security Program in 1956, but in this case eligibility is restricted to those workers under normal retirement age and who have worked in at least five of the last ten years and can no longer hold gainful employment owing to disability. Spending on DI, and to a lesser extent SSI, has been startling not only in magnitude, but in its stealth nature. That is, unlike other social insurance programs covering retirees or the unemployed that receive extensive coverage from policymakers and the press, the rise in disability has taken place largely out of public view and yet DI was the third fastest growing social insurance program and annual appropriation on DI was $\$ 121$ billion in 2009. This growth in outlay in the last decade has taken place not because of any major policy reform (1984 was the last major reform). Rather, as argued convincingly by Autor and Duggan (2006), it emanates from changes in the implementation of program rules that result in a greater fraction of awards conditional on applying, coupled with a greater fraction of the population applying for benefits. The latter it seems stems both from a decade-long slump in employment growth and a larger pool of potential workers from the increase in female labor force participation post 1970.

The remaining major social insurance programs are UI and workers comp. These programs were the first in the safety net, having been established in several states in the first two decades of the $20^{\text {th }}$ century. They are also unique among social insurance programs in the federal-state partnership that underlies funding and administration (several means-tested programs are federal-state partnerships). To qualify for workers comp a person must have a temporary or permanent work-related injury or illness that precludes working at the pre-injury job or one similar to it. Nearly three-fourths of benefits are paid out as medical only benefits, 
with the remainder quarter as cash-replacement benefits or both. ${ }^{3}$ There have been no major policy changes at the federal level in recent years, though some states have altered benefit eligibility and payment in order to rein in costs. As a consequence, real spending has been fairly stable over the decade.

The UI system was codified into federal law as part of the 1935 Social Security Act, but major responsibility for program rules and administration largely rests at the state level. Today, virtually the entire civilian labor force is eligible for UI benefits provided they meet basic work criteria. Specifically, unless they are a new labor market entrant awaiting the start of a job, the claimant must have worked in covered employment in the first four out of the last five calendar quarters, must not have voluntarily left their job, must be able to work, and must be actively seeking work. Conditional on passing the work test, benefit amounts vary widely across states, though typically it is a function of past wages in the base period used for eligibility, subject to a cap. Normal UI receipt lasts up to 26 weeks, but the Extended Benefits Program that is triggered in periods of high unemployment allows for extensions up to 13 weeks. In response to the deep recession, in June 2008 Congress passed the Emergency Unemployment Compensation Program that added an additional 13 weeks of federally funded UI benefits. This was amended in November 2008, and again in November 2009, so that certain workers in high unemployment states could qualify for as much as 99 weeks of benefits. The nearly four-fold increase in real UI benefits to $\$ 122$ billion by 2009 is unprecedented, reflecting the larger pool of unemployed from the protracted weak labor market, the duration of unemployment, and direct Congressional action extending eligibility.

\footnotetext{
${ }^{3}$ http://www.socialsecurity.gov/policy/docs/statcomps/supplement/2010/workerscomp.pdf
} 


\section{Means-Tested Transfers}

The Medicaid program was established in 1965 alongside the Medicare program. The population served differs in that Medicaid is targeted to low-income and low liquid asset individuals and families, and is the largest of the means-tested transfer programs. Funding for the program is shared by federal and state governments, and many program parameters relating to eligibility and benefit coverage are set at the state level. Historically the majority of recipients have been single mothers and their dependent children, though the majority of outlays are spent on poor seniors requiring institutionalized care (e.g. hospital and nursing home). Like Medicare, the 50 percent increase in the spending over the past decade reflects to some extent the aging of the population (i.e. more seniors require extended care in hospital or nursing homes), as well as the above average medical care inflation. It also reflects higher caseloads resulting from the weak economy and expanded eligibility in many states starting in the 1990s for families with income 2-3 times the federal poverty line. Going forward, spending on Medicaid is expected to grow substantially both from care of the aged indigent, and as a result of the Affordable Care Act of 2010 that will expand Medicaid eligibility to all families with incomes below 138 percent of the federal poverty line starting in 2014.

The SSI program, which was added to the Social Security Program in 1972, provides cash assistance to the needy aged, the blind, and the disabled. While identifying potential recipients based on age and vision is readily assessed, verifying disabilities is difficult and fraught with controversy. As described in Daly and Burkhauser (2003) there is a three-step process in identifying disabilities: (i) a physical or mental malfunction that (ii) leads to an impairment which in turn (iii) generates an inability to perform socially expected functions, notably work for adults and schooling for children. Challenges notwithstanding, the bulk of the 
SSI caseload are disabled recipients, notably those suffering from mental impairments. On top of the programmatic criteria of being aged, blind, or disabled, to qualify for SSI the family must meet both income and liquid asset tests. The SSI program has substantial federal oversight, with grant and eligibility criteria set at the federal level, along with statutory benefit reduction rates on earned and unearned incomes. On top of federal aid, about half of the states supplement the federal grant for individuals living independently. Aside from a series of changes to SSI in the 2000s that restored benefit eligibility for certain immigrant groups who had lost coverage as part of the 1996 welfare reform, there have been no substantive changes in SSI policy in the last decade that would lead to the 20 percent growth in real spending, and instead likely reflect the overall increase in disability awards also affecting the DI program.

As noted previously, the 1996 welfare reform replaced the former AFDC program with the block granted TANF program. States actually began experimenting with their welfare programs in the early-1990s via waivers from federal regulations granted by the U.S. Department of Health and Human Services (DHSS). These waivers included time limits on benefit receipt, work requirements, and work incentives such as higher earnings disregards and liquid-asset limits. The waivers were codified into federal legislation with the passage of PRWORA. Under PRWORA, cash assistance is no longer an entitlement and aid is subject to a federal lifetime limit of 60 months (or shorter based on state discretion). Under AFDC about 70 percent of spending was paid as cash benefits and the remainder as in-kind, but today the TANF program spends about 70 percent of resources on in-kind programs and 30 percent on cash benefits. The Deficit Reduction Act of 2005 reauthorized the TANF program and in the process strengthened rules governing work participation. However, a 2010 GAO report suggests little change in the 
ensuing years in TANF work participation rates. ${ }^{4}$ Although the federal block-grant contribution to the program has remained fixed in nominal terms at $\$ 16.6$ billion since the 1996 reform, states increased funding during the recession and as part of ARRA 2009 the federal government provided additional TANF funds. These changes have kept real state and federal spending on TANF unchanged over the last decade.

The Supplemental Nutrition Assistance Program (SNAP) provides food assistance to low-income and low-asset persons without regard to age and family structure, and thus the target population is broader than either Medicaid or TANF. As part of the 2008 Farm Bill, SNAP replaced the former Food Stamp Program primarily in name only in a bid to reduce perceived stigma associated with use of food stamps. Indeed the name change is left to state discretion and only 25 of the 50 states plus the District of Columbia have adopted the SNAP moniker. The remaining half either kept the former food stamp name or adopted an alternative. The program rules, benefits, and funds are set primarily at the federal level, with the benefits indexed to inflation. Recipients of TANF or SSI are categorically eligible for SNAP, though evidence in Ziliak, Gundersen, and Figlio (2003) suggests that the links between TANF and SNAP appear to have weakened after PRWORA.

While most of 1990s welfare reform was directed at the AFDC program, food stamps was not devoid of reforms of its own, notably the phasing out of paper coupons with Electronic Benefit Transfer cards, and restrictions on benefit receipt among both legal immigrants and socalled ABAWDS, able bodied adults without dependents working less than 20 hours per week. Among other changes, the 2002 Farm Bill restored eligibility for most of the legal residents removed by PRWORA and liberalized financial eligibility rules, notably asset tests. In 2008

\footnotetext{
${ }^{4}$ http://www.gao.gov/new.items/d10525.pdf
} 
states were given the option of increasing or removing both the vehicle and liquid asset tests and most have chosen that option. Unlike the TANF program, SNAP participation moves countercyclically with the business cycle, and thus the more than doubling in expenditures since 1999 resulted in part from the weak economy. Spending rose also in 2009 as part of ARRA that temporarily raised benefits by an average of just under 14 percent.

The housing assistance program is unique among means-tested transfers because of its decentralized administration at the local level. Today there are more than 2,400 local housing authorities charged with setting guidelines on program eligibility for either public housing or Section 8 vouchers. Public housing in the U.S. began during the Great Depression and then developed in earnest after WWII. Currently there are over 14,000 units nationwide serving nearly 2.3 million people, the majority of whom are either elderly or disabled. ${ }^{5}$ Because of lack of investment maintaining the properties, during the past two decades many housing units have been demolished and replaced with Section 8 vouchers. These vouchers subsidize the rent on privately owned units (though a portion is dedicated to publicly owned). Individuals are expected to cover the first 30 percent of monthly rent, and then the voucher covers the remainder subject to a cap. Eligibility varies across housing authorities, but the basic income test requires family income to be less than some percentage of county median income, e.g. less than 50 percent of median. Because of excess demand for vouchers and public housing, most authorities have created waiting lists that can be several years long. Many have simply closed waiting lists.

The final program covered in this section is the Earned Income Tax Credit, which is a refundable tax credit that is available to low-income working families and individuals. The growth of the EITC began with Tax Reform Act of 1986, followed by even more extensive changes with OBRA 1990 and OBRA 1993. The latter Acts altered the credit to be more

\footnotetext{
${ }^{5}$ http://www.cbpp.org/cms/index.cfm?fa=view\&id=2528
} 
generous for families with two or more qualifying children and also extended the credit to childless workers. Additionally, ARRA added a third tier by increasing the subsidy rate to 45 percent for families with 3 or more qualifying children for the 2009 and 2010 tax years. The Tax Relief and Job Creation Act of 2010 extended this feature for the 2011 and 2012 tax years, and an earlier provision eliminated the Advance EITC option. As a consequence of the changing labor force composition and policy, expenditures on the EITC make it the largest cash assistance program to low-income working persons.

\section{Antipoverty Policy and Antipoverty Effectiveness}

In light of the growth of social insurance and mean-tested transfer programs over the past decade, I examine whether these additional expenditures have resulted in any trend break in poverty. The analysis is descriptive and thus causal claims will not be made; however, as a first step in understanding the role of the safety net in eradicating poverty it is instructive to document how poverty levels in America change once cash and in-kind transfer programs are accounted for in poverty measurement.

I consider three measures of income that reflect an individual's resource base to avoid poverty: (1) pre-tax and transfer income; (2) the sum of (1) and cash social insurance and meanstested transfers; and (3) the sum of (2), in-kind insurance and transfer program contributions, and net capital gains, less net tax payments. Definition (2) is the same as that used by the Census Bureau for official poverty statistics, and thus in comparing resource measure (1) to (2) we observe how the level of poverty is affected by government cash payments. Because net capital gains tends to be minimal for most low-income families, comparing measure (2) to (3) permits us 
to observe how poverty changes with the inclusion of in-kind payments, as well as tax payments and credits.

The data come from the Annual Social and Economic Supplement of the Current Population Survey for calendar years 1999-2009 (interview years 2000-2010), which is used by the U.S. Census Bureau to provide official estimates of poverty and inequality. The Data Appendix provides details on the sample and how the income measures are constructed. It is instructive to highlight, however, how in-kind transfers are defined here. In-kind benefits include so-called near-cash transfers such as SNAP, school breakfast and lunch, and subsidized housing. These are in-kind benefits with a near dollar for benefit market value. I also include health benefits from the Medicaid and Medicare programs, which are much more difficult to value. They are typically valued either at market values, that is, the amount that it costs to obtain similar products in the private market, or at less than market rates, what the Census Bureau calls “fungible value" (Census P60-186RD 1992). In the CPS families are assigned fungible values if and only if their family income exceeds that which is needed for food and housing under the proviso that extra resources exist to purchase private health benefits. If family income falls short of food and housing needs then the fungible value is zero; otherwise, the fungible value equals the difference between family income and food and housing expenses up to the market value of medical benefits. The implication then is that fungible values of health benefits will be small or nonexistent for many poor families.

\section{Incidence of Poverty}

The first measure of safety-net antipoverty effectiveness I consider is the poverty rate, sometimes known as the "headcount rate.” The poverty rate represents the percentage of the 
population that is poor, $\frac{Q}{N}$, where $N$ is the size of the population and $Q$ is the number of poor persons. Specifically, if we let $y$ denote a person's income and $z$ a pre-established poverty line, then a person is poor if $y<z$ and not poor if $y \geq z$. In this case poverty is a discrete state reflecting the fraction of persons who have not yet attained a minimally adequate level of income to meet basic socially determined needs. In the U.S. the poverty line varies by family size and is adjusted over time by changes in inflation, but otherwise it represents the same fixed basket of goods and services since its inception in the 1960s and thus the U.S. measure is considered an absolute poverty measure (Fisher 1992). While this definition is transparent, it is also vague because the notion of poor depends on the resources being measured and where the cutoff separating the poor from the non-poor is drawn, each of which may be subjectively determined across time and space.

[Figure 1 and Table 2 here]

Figure 1 depicts trends in poverty rates from 1999 to 2009, and Table 2 contains the corresponding estimates of the number of persons in poverty. From 1999 to 2007 pre-tax and transfer poverty rates held steady at about 21 percent of the population, but with a growing population the number in poverty rose by 7.5 million from 54.8 million to 62.4 million. In the suing two recessionary years, pre-tax and transfer poverty rates increased nearly 4 percentage points (18 percent on the baseline of 20.9 percent) and an additional 12.5 million Americans fell into poverty. The official poverty rate likewise rose from 11.8 percent of the population in 1999 to 14.3 percent in 2009, and with a post-2007 increase of nearly 2 percentage points (or 15 percent on a baseline of 12.5 percent). As seen in Table 2, in a typical year cash transfers and social insurance lift 41 percent of the pre-tax and pre-transfer poor out of poverty. Once we 
account for in-kind transfers such as SNAP, Medicaid, and Medicare, as well as tax payments and the EITC, an additional 16 percent are lifted out of poverty over and above the official rate. Combined the safety reduces pre-tax and transfer poverty by just over one-half. However, even though expenditures on these programs increased substantially over the past decade, the antipoverty effectiveness in terms of the headcount ratio has been fairly steady. There was a noticeable boost in 2009 relative to 2008 as a result of ARRA, but perhaps not as large as might be expected given the level of appropriation. Part of this, of course, is explained by the fact that many beneficiaries of SNAP and UI are not living below the poverty line.

[Figure 2 here]

Figure 2 explores in more detail the contribution of each component of the after-tax and in-kind transfer measure to poverty reduction by highlighting how many persons are removed (or added in the case of taxes) from poverty each year. This is computed by taking the official Census income definition as the baseline and adding each tax or in-kind transfer separately. In a typical year between 1999 and 2007 the EITC lifted about 4 million persons out of poverty, but with the deep recession and extensions as part of ARRA, just over 5 million were lifted out of poverty in 2009. The antipoverty effectiveness of SNAP accelerated over the decade, with about 2 million lifted out of poverty each year through 2003, but that figure more than doubled to 4.5 million in 2009, again both owing to the deep recession and expanded benefit generosity in response to the recession. Capital gains, owing to the rarity of low-income persons receiving capital income, and housing benefits, owing to the relatively low participation in the programs, do little to lift families out of poverty. The individual income tax system (federal, state, payroll) has the opposite effect of reducing disposable income and thus in a typical year between 1999 and 2005 resulted in about 3.5 million more in poverty. This grew rapidly in the next two years 
as low and moderate income persons gained traction in the labor market (note in Figure 1 the decline in pre-tax and transfer poverty), but then there is evidence of "regression to the mean” by 2009 with a return to pre-2006 levels of persons placed into after-tax income poverty.

[Figure 3 here]

An important barometer of the safety net is how well it provides support to our more vulnerable populations of children and aged. In Figure 3 I depict the number of adults 65 and older and the number of children under age 18 in poverty across the three income measures for both 1999 and 2009. The figure shows that on a pre-tax and transfer basis that slightly more seniors are in poverty than children, but on post-tax and transfer basis there is a yawning gap in the numbers of children left in poverty compared to the elderly. In 1999 the number of seniors in poverty after accounting for taxes and transfers was 83 percent lower than the pre-tax basis, compared to 37 percent lower among children. In 2009 the comparable figures were 85 percent and 41 percent, suggesting that the ARRA expansions of SNAP and EITC helped children more than adults, but still the numbers children lifted out of poverty by the safety net was less than half that of seniors.

\section{Intensity and Depth of Poverty}

A common complaint levied against the headcount rate is its failure to account for the intensity of poverty. That is, individuals $\$ 500$ below the threshold are given the same weight as those $\$ 5000$ below the threshold, even though most would agree that the deprivation of the latter likely far outweighs the deprivation of the former. A transparent alternative that captures the intensity of poverty is the so-called poverty gap (Ziliak 2006; Ben-Shalom, et al. 2011), defined 


$$
\text { gap }=\sum_{q=1}^{Q} \max \left\{z-y_{q}, 0\right\}, \text { for } Q \leq N
$$

This measure reflects the aggregate income deficit among the poor population; that is, for each poor person we compute how much money they would require to be lifted up to the family-size specific poverty line, and then add this deficit up across the entire population of poor persons. For persons above the line, $y>z$, the gap is zero. The attraction of the poverty gap is that it is expressed in dollars, and while this means that the measure is not scale invariant (i.e. will differ under different currencies), it does permit an examination of how the intensity of poverty changes with the safety net under stable units.

\section{[Table 3 and Figure 4 here]}

Table 3 presents estimates of the aggregate poverty gap for the three alternative resource measures, expressed in billions of real 2010 dollars. In the table, $Q$ refers to the number of pretax and transfer poor. That is, in the first column we add up the pre-tax and transfer poverty gap among the pre-tax and transfer poor. In the column labeled Official the exercise is "among those who were pre-tax and transfer poor, how much of the gap remains after we account for cash social insurance and means-tested transfers?” Likewise, in the after-tax and transfers column the exercise is "among those who were pre-tax and transfer poor, how much of the gap remains after we account for cash social insurance and means-tested transfers, as well as in-kind transfers and taxes?” In 1999, among the pre-tax and transfer poor, the amount of money required to lift all (pre-tax and transfer) poor persons out of poverty was \$261 billion. By 2009 \$385 billion was required, or an increase of 48 percent. Using the official resource definition the aggregate gap in 1999 was 61 percent lower at \$102 billion needed to lift all officially poor persons out of poverty. The estimate in 2009 was $\$ 155$ billion, or 52 percent higher, which suggests that the 
cash transfer safety net has slipped in its effectiveness of reducing the intensity of poverty. Once we add in-kind transfers along with net tax payments the aggregate gap falls by about two-thirds in comparison to the pre-tax and transfer gap (comparing column (3) to (1)). Again, however, even with the broadest measure of income the aggregate gap increased 50 percent between 1999 and 2009, suggesting that the safety net is losing some of its antipoverty bite.

Figure 4 depicts aggregate poverty gaps for children and the elderly in 1999 and 2009. The figure underscores how much more the safety net reduces the intensity of poverty among older Americans relative to children. The safety net in both years fills 92 percent of the gap among those 65 and older, and under 60 percent among children. There was a slight improvement in filling the gap among children between 1999 and 2009, increasing from 57 percent to 59 percent. This suggests that the reduced antipoverty effectiveness identified in Table 3 comes from adults between the ages of 18 and 64 .

\section{[Figures 5 and 6 here]}

Along with the intensity of poverty it is instructive to examine how the safety net affects the depth of poverty. Although there are many axiomatically derived measures of deep poverty (e.g.Foster, Greer, and Thorbecke 1984), here I consider the simple measure used by the Census Bureau and that is the fraction of the population living below one-half of their family-size specific poverty threshold, i.e. $\sum_{n=1}^{N} I\left(y_{n}<0.5 * z\right)$, where $I($.$) is an indicator variable taking on$ a value of 1 if income is below half the threshold and 0 otherwise. Figure 5 depicts trends in deep poverty for the population overall, and Figure 6 separately by children and the elderly. Figure 5 shows that by 200916 percent of the population had pre-tax and transfer incomes below one-half of the poverty threshold, about 6.3 percent of the officially poor were in deep poverty, 
and 4.6 percent of the post-tax and in-kind transfer poor were in deep poverty. These rates are 28.6, 34.9, and 34.4 percent higher than their 1999 counterparts, respectively, again suggesting that the safety net expansions over the past decade are not keeping up with the increasing deprivation facing the extreme poor. Have the ARRA expansions fared better? The answer seems a qualified yes. Between 2007 and 2009 pre-tax deep poverty increased 19 percent from 13.9 to 16.4 , and deep poverty as measured by official resource definition increased 20 percent. However, post-tax and in-kind transfer deep poverty increased a lower 15 percent between 2007 and 2009, most likely owing to increased SNAP receipts. Among children in Figure 6, the comparable increases from 2007 to 2009 were 25 percent, 19 percent, and 11 percent, suggesting that very poor children were disproportionately exposed to the economic downturn, but the ARRA expansions likely ameliorated their situation more than other groups.

\section{Inequality of Poverty}

A primary objective of the safety net is to equalize post-tax and transfer incomes across the population. Although there has been extensive research on trends in wage inequality (Katz and Autor 1999), and most recently top income inequality (Atkinson, Piketty, and Saez 2011), there has been comparatively less on the effect of the safety net on income inequality (Karoly 1994), especially at the lower tail of the distribution. Because my objective is to compare how inequality changes as the resource definition is expanded to account for the safety net, for ease of presentation I first adopt a summary measure of inequality. Specifically I use the normalized

coefficient of variation, $\frac{C V}{1+C V}$, which is bounded below by 0 reflecting no inequality and above by 1 reflecting perfect inequality. The $C V$ is measured as the ratio of the standard deviation of income to its mean. 
[Figures 7 and 8 here]

Figure 7 depicts trends in overall income inequality, showing that pre-tax and transfer income inequality increased over the past decade from 0.52 to 0.56 , and where most of the increase occurred between 1999 and 2000. The addition of cash transfers and social insurance contained in the official resource measure reduces inequality by about 5 percent in a typical year, and while this is fairly stable over most of the decade, there is some evidence of additional redistributive effectiveness over the past couple of years. Expanding the resource definition to include taxes and in-kind transfers reduces pre-tax inequality by 11 percent in a typical year, and this redistributive function actually increased by 24 percent since 1999 (and 13 percent alone between 2007 and 2009). This is suggestive that the expanding safety net at the end of last decade played an important redistributive role overall. We see this further in Figure 8 with the ratio of the $90^{\text {th }}$ percentile to the $10^{\text {th }}$ percentile of the income distribution for the official census measure and after-tax and transfer income (the $10^{\text {th }}$ percentile is 0 for the pre-tax and transfer measure, and thus the 90-10 ratio is undefined). In 1999 the after-tax and in-kind transfer 90-10 ratio is 26 percent lower than the official Census measure, and this increases to 28 percent lower in 2009, suggesting again that expanded SNAP and EITC modestly helped the lower tail of the distribution.

[Figure 9 here]

Figure 9 presents the parallel set of inequality trends as in Figure 7 for the subpopulation of poor persons (based on the official poverty definition). The story is more complicated among the poor as pre-tax and transfer inequality has been unchanged over the decade, and cash transfers have consistently reduced inequality by about 23 percent in a typical year, the exception 
being 2009 when it lowered inequality by a more modest 21 percent. Perhaps surprising, the post-tax and in-kind transfer safety net actually exacerbates among the poor. A closer examination reveals that as expected the mean level of income increases with in-kind transfers and tax credits, but the variance increases by more, thus resulting in higher inequality than cash income alone. This could occur, for example, because of differential participation rates among the poor in in-kind transfers and credits, especially in light of the fact that the poor contain both workers and nonworkers and the EITC is only available to those who work in the labor market.

\section{Volatility of Income}

Although much of economic research is aimed at quantifying the costs of the safety net in terms of reduced incentives to work, save, consume, and marry, more recently there has been interest in quantifying the benefits of social programs and taxation in terms of reduced economic volatility (Gruber 2000; Kniesner and Ziliak 2002; Blundell and Pistaferri 2003; Huggett and Parra 2010). This is important because a central goal of economic policy is to stabilize household consumption in the presence of adverse economic events, whether the shocks are economy wide or idiosyncratic. Most transfers are explicit in their stabilizing role because they provide direct cash or near-cash income support. Progressive income taxes of the sort found in the U.S. provide implicit insurance because when before-tax income falls the household's tax burden also falls so that after-tax spendable income drops by less than the drop in pre-tax income. Combined the U.S. tax and transfer system should reduce the volatility of income.

To measure volatility I adopt the metric employed by Ziliak, Hardy, and Bollinger (2011) for earnings volatility; namely the standard deviation of the arc percent change defined as 


$$
\text { volatility }=\sqrt{\operatorname{Var}\left\{100 * \frac{y_{i t}-y_{i t-1}}{\bar{y}_{\imath}}\right\}},
$$

where $y_{i t}$ is income for person $i$ in time $t$, and $\bar{y}_{l}=\frac{y_{i t}+y_{i t-1}}{2}$, is the person-specific time mean across the matched pair of years. The key advantages of this measure over the variance of log income is that it is defined even if income is zero in one of the two years, and that it is symmetric and bounded below by -200 percent and above by +200 percent. However, the symmetry property is violated if income is negative one year, say due to a business loss, and positive the next. As a consequence, Ziliak, et al. modify the arithmetic mean in the denominator as $\overline{y_{l}}=$ $\frac{a b s\left(y_{i t}\right)+a b s\left(y_{i t-1}\right)}{2}$, where $a b s($.$) refers to the absolute value. This modified measure at once$ permits negative incomes and retains the symmetry property of -200 percent and +200 percent.

[Figures 10 and 11]

Figures 10 and 11 depict trends in income volatility over the past decade for the population overall and those living in poverty. As described in the appendix, the data for this analysis comes from the March CPS whereby I exploit the longitudinal dimension of the survey design that permits linking of the same individual across two consecutive years. The unit of analysis is the head of household for those families with the same head in both years. The poverty sample in Figure 11 imposes the additional restriction that the family remain in poverty for both years (as defined by the official definition). Figure 10 reveals that income volatility across all measures was fairly stable over the decade, with the possible exception of pre-tax and transfer income volatility that showed signs of increasing during the recent recession. The safety net plays a big role in reducing income volatility-the post-tax and in-kind transfer series is about 30 percent lower than the pre-tax and transfer counterpart in an average year. This income smoothing increased during the recession, likely in response to ARRA programs. 
Figure 11 shows that among the poor the level of income volatility is much higher (by about 70 percent) in any given year relative to the population as a whole, and that the trend in pre-tax and transfer volatility actually declined after 2006. Again the safety net plays a vital role for the poor in that in a typical year income volatility after-tax and in-kind transfers is 40 percent lower compared to pre-tax and transfer income. This effect is one-third larger than for the population overall. On the contrary Figure 11 also shows a trend increase in the volatility of income once the safety net programs are accounted for in the resource measure. In fact the official measure smoothes income volatility 25 percent less in 2009 than in 1999, while the aftertax and in-kind transfer measure smoothes 12 percent less, suggesting that the effectiveness of the explicit and implicit insurance provided by the safety net is weaker in the current downturn for the poor.

\section{Conclusion}

I provide an overview of recent developments in antipoverty policy in the United States and then document how the growth in social insurance and means-tested transfers have affected income poverty, inequality, and volatility using data from the CPS. I find that with few exceptions real spending on the safety net increased substantially in the past decade, owing primarily to demographic shifts and business cycles rather than fundamental policy reforms.

In 1999 the safety net lifted nearly 30 million Americans out of poverty, and in 2009 nearly 40 million were lifted above the poverty line, but in each year this translates into just over 50 percent of the pre-tax and pre-transfer poor. Thus, despite the increased spending the antipoverty effectiveness of the safety net was little changed. Indeed, I provide evidence that this enhanced spending has not necessarily translated into improved economic status of the poorest 
poor in America as the intensity and volatility of after-tax and transfer poverty have increased in recent years.

What likely accounts for the lackluster performance of the safety net in combating poverty, especially deep poverty? Part of the reason owes to the fact that the social insurance programs in the safety net are not targeted directly to the poor. This implies that the growth in Social Security, Medicare, UI, DI, and workers comp could in fact be improving the outcomes of middle class families rather than the poor per se. Likewise, among means-tested transfers, the growth in Medicaid occurred among those with gross incomes one to two times the poverty line, and SNAP growth likely occurred among households recently suffering job loss and some of those have gross incomes above the poverty line (recall SNAP eligibility extends to 130 percent of poverty). In addition, the near 50 percent increase in the EITC clearly improved the employment of single mothers with dependent children, but evidence in Ziliak (2009) suggests that among low-skilled single mothers the combination of welfare reform and the EITC expansions resulted in lower after-tax and transfer incomes. The higher earnings coupled with EITC supplements were insufficient to offset the loss of other transfer income among those in deep poverty. These trends suggest that future policy reforms need to be directed at improving the outcomes of the truly disadvantaged. 


\section{Data Appendix}

The data derive from the 2000-2010 waves (1999-2009 calendar years) of the March Annual Social and Economic Study of the Current Population Survey (CPS). The CPS is the data source used in constructing official poverty statistics in the U.S., and I follow the same method. Specifically the unit of analysis is noninstitutionalized families (including related subfamilies) and unrelated individuals. The survey is fielded in March and the income information refers to the previous year. The family is the basic unit of analysis for poverty measurement, where family means two or more persons residing together and related by marriage, birth, or adoption. The income of all family members is summed to yield total family income for the year, and members of related subfamilies are assigned the family income of the primary family unit.

In the United States economic resources for the purposes of poverty measurement entail highly liquid forms of money income. This includes earnings, Social Security (retirement, disability, and survivors benefits), Supplemental Security Income, Unemployment Insurance, workers' compensation, Temporary Assistant to Needy Families and other forms of public cash welfare, veterans' payments, pension income, rent/interest/dividend income, royalties, income from estates, trusts, educational assistance, alimony, child support, assistance from outside the household, and other income sources. Income, as defined above, is summed up across all income-earning family members and the total is compared to the poverty threshold for that family's size. The threshold is updated annually by changes in the Consumer Price Index-All Urban Consumers, thus making poverty comparisons over time inflation adjusted. All individuals in the family are assigned the same poverty status, related subfamilies are assigned the poverty status of the prime family, and unrelated individuals are assigned the poverty status 
based on their own income and relevant threshold. There are several groups of individuals not accounted for in this definition including unrelated individuals under age 15 (such as foster children), and those individuals who are institutionalized, living in college dorms, military barracks, or the homeless living outside of shelters. All estimates are weighted using the individual weight supplied by the Census Bureau.

In addition to official poverty rates, I consider two alternative definitions of income. The first is pre-tax and pre-transfer income, which only includes income from private sources and thus excludes any form of government transfer payments. The second is after-tax and in-kind transfer income. This measure is similar to the definition of resources recommended by the National Academy of Sciences Panel on Poverty Measurement (Citro and Michael 1995). This measure adds to the official Census income definition net capital gains as well as the dollar value of near-cash in-kind transfers like food stamps (Supplemental Nutrition Assistance Program), school lunch, and housing subsidies. It also adds the imputed value of the Earned Income Tax Credit and subtracts federal, state, and payroll tax payments. Moreover, I include the imputed value of Medicaid and Medicare. Health benefits are typically valued either at market values, that is, the amount that it costs to obtain similar products in the private market, or at less than market rates, what the Census Bureau calls "fungible value" (Census P60-186RD 1992). In the CPS families are assigned fungible values if and only if their family income exceeds that which is needed for food and housing under the proviso that extra resources exist to purchase private health benefits. If family income falls short of food and housing needs then the fungible value is zero; otherwise, the fungible value equals the difference between family income and food and housing expenses up to the market value of medical benefits. 
The sample selection used in constructing measures of income volatility differs from that used in constructing poverty rates and gaps. Specifically, I follow Ziliak, et al. (2011) by noting that the rotating design of the CPS means that a respondent is in sample for 4 months, out 8 months, and in another 4 months, and this makes it possible to match approximately one-half of the sample from one March interview to the next. Following the recommended Census procedure I perform an initial match of individuals on the basis of five variables—month in sample (months 1-4 for year 1, months 5-8 for year 2); gender; line number (unique person id); household identifier; household number; and state of residence. I then cross check the initial match on two additional criteria: race and age of the individual. If the race of the person changed I delete that observation. Also, if the age of the person fell, or if age increased by more than two years (owing to the staggered timing of the initial and final interviews), then I delete those observations on the assumption that they were bad matches. Unlike Ziliak, et al., I do not eliminate observations with allocated incomes or adjust for CPS changes in top coding procedures over time.

All income data used in constructing the measures of poverty gaps, inequality, and volatility is deflated by the Personal Consumption Expenditure Deflator with 2010 base year. 


\section{References}

Atkinson, Anthony, Thomas Piketty, and Emmanuel Saez. 2011. "Top Incomes in the Long Run of History.” Journal of Economic Literature 49(1): 3-71.

Autor, David, and Mark Duggan. 2006. "The Growth in Social Security Disability Rolls: A Fiscal Crisis Unfolding.” Journal of Economic Perspectives, 20(3): 71-96.

Autor, David, and Mark Duggan. 2010. Supporting Work: A Proposal for Modernizing the U.S. Disability Insurance System, Washington, DC: Center for American Progress and The Hamilton Project.

Bane, Mary Jo, and David R. Ellwood. 1996. Welfare Realities: From Rhetoric to Reform. Cambridge, MA: Harvard University Press.

Ben-Shalom, Yonatan, Robert Moffitt, and John Karl Scholz. 2011. "An Assessment of the Effectiveness of Anti-Poverty Programs in the United States," In Oxford Handbook of Economics of Poverty, P. Jefferson, editor, Oxford, U.K.: Oxford University Press, forthcoming.

Blank, Rebecca. 1997. It Takes a Nation: A New Agenda for Fighting Poverty. Princeton, NJ: Princeton University Press.

Blank, Rebecca. 2009. "What We Know, What We Don't Know, and What We Need to Know about Welfare Reform.” In Welfare Reform and its Long Term Consequences for America's Poor, (J. Ziliak, ed.), Cambridge, UK: Cambridge University Press, 22-58.

Blundell, Richard and Luigi Pistaferri. 2003. "Income Volatility and Household Consumption: The Impact of Food Assistance Programs.” Journal of Human Resources, 38(Supplement): 1032-1050.

Citro, Constance, and Robert Michael. 1995. Measuring Poverty: A New Approach, Washington, D.C.: National Academy Press.

Currie, Janet. 2006. The Invisible Safety Net: Protecting the Nation's Poor Children and Families, Princeton, NJ: Princeton University Press.

Daly, Mary, and Richard Burkhauser. 2003. "Left Behind: SSI in the Era of Welfare Reform." Focus 22(3): 35-43.

Fisher, G. 1992. "The Development of the Orshansky Poverty Thresholds and Their Subsequent History as the Official U.S. Poverty Measure.” http://www.census.gov/hhes/poverty/povmeas/papers/orshansky.html .

Foster, James, Joel Greer, and Erik Thorbecke. 1984. "A Class of Decomposable Poverty Measures.” Econometrica 52(3): 761-766. 
Grogger, Jeffrey, and Lynn A. Karoly. 2005. Welfare Reform: Effects of a Decade of Change. Cambridge, MA: Harvard University Press.

Gruber, Jonathan. 2000. "Cash Welfare as a Consumption Smoothing Mechanism for Divorced Mothers.” Journal of Public Economics 75(2): 157-82.

Haskins, Ronald. 2007. Work over Welfare: The Inside Story of the 1996 Welfare Reform Law. Washington, DC: Brookings Institution Press.

Haskins, Ron, and Isabel Sawhill. 2009. Creating an Opportunity Society. Washington, DC: Brookings Institution Press.

Heinrich, Carolyn, and John Karl Scholz. 2009. Making the Work-Based Safety Net Work Better, New York, NY: Russell Sage Foundation.

Hotz, V. Joseph, and John Karl Scholz. 2003. “The Earned Income Tax Credit.” In Means-Tested Transfer Programs in the United States, R. Moffitt (ed.), Chicago: The University of Chicago Press and NBER, 141-197.

Huggett, Mark, and Juan Carlos Parra. 2010. "How Well Does the U.S. Social Insurance System Provide Social Insurance?” Journal of Political Economy, 2010, 118, 76-112.

Karoly, Lynn A. 1994. "Trends in income inequality: the impact of, and implications for,tax policy.” In Tax Progressivity and Income Inequality, Joel Slemrod (ed.), Cambridge, UK: Cambridge University Press, 95-129.

Katz, Lawrence and David Autor. 1999. "Changes in the Wage Structure and Earnings Inequality.” In Handbook of Labor Economics 3A, O. Ashenfelter and D. Card (eds.), Amsterdam: North Holland, 1463-1555.

Kniesner, Thomas J., and James P. Ziliak. 2002. “Explicit versus Implicit Income Insurance,” Journal of Risk and Uncertainty, 25(1): 5-20.

Krueger, Alan, and Robert Solow. 2001. The Roaring Nineties: Can Full Employment Be Sustained? New York: The Russell Sage Foundation.

Kubik, Jeffrey. 1999. "Incentives for the Identification and Treatment of Children with Disabilities: The Supplemental Security Income Program.” Journal of Public Economics 73(2): 187-215.

Moffitt, Robert. 2003. Means-Tested Transfer Programs in the United States, Chicago: The University of Chicago Press and NBER.

Murray, Charles. 2006. In Our Hands: A Plan to Replace the Welfare State. Washington, DC: AEI Press. 
Schmidt, Lucie, and Purvi Sevak. 2004. "AFDC, SSI, and Welfare Reform Aggressiveness: Caseload Reductions versus Caseload Shifting.” Journal of Human Resources 39(3): 792-812.

Ziliak, James P. 2006. “Understanding Poverty Rates and Gaps: Concepts, Trends, and Challenges,” Foundations and Trends in Microeconomics, 1(3): 127-199.

Ziliak, James P. 2009. Welfare Reform and its Long Term Consequences for America's Poor, Cambridge, UK: Cambridge University Press.

Ziliak, James P., Craig Gundersen, and David Figlio. 2003. "Food Stamp Caseloads Over the Business Cycle,” Southern Economic Journal 69(4): 903-919.

Ziliak, James P., Bradley Hardy, and Christopher Bollinger. 2011. "Earnings Volatility in America: Evidence from Matched CPS,” Labour Economics, forthcoming. 
Table 1. Expenditures on Selected Social Insurance and Means

Tested Transfer Programs

\begin{tabular}{|c|c|c|}
\hline & 1999 & 2009 \\
\hline \multicolumn{3}{|l|}{ Social Insurance } \\
\hline OASI & 424 & 568 \\
\hline Medicare & 270 & 519 \\
\hline Disability Insurance & 65 & 121 \\
\hline Workers Compensation $^{\mathrm{a}}$ & 55 & 59 \\
\hline Unemployment Insurance & 26 & 122 \\
\hline \multicolumn{3}{|l|}{ Means Tested Transfers and Credits } \\
\hline Medicaid & 260 & 392 \\
\hline Supplemental Security Income & 39 & 47 \\
\hline TANF & 29 & 29 \\
\hline Food Stamps/SNAP & 23 & 55 \\
\hline Housing Assistance $^{\mathrm{a}}$ & 36 & 41 \\
\hline Earned Income Tax Credit & 40 & 59 \\
\hline
\end{tabular}

Note: The data are billions \$2010. They are drawn from selected years of the Statistical Abstract of the United States, 2010 Social Security Bulletin-Annual Statistical Supplement , and USDA and IRS Websites. ${ }^{\mathrm{a}}$ Data from 2008. 
Table 2. Millions of Persons in Poverty by Alternative Resource Definition

\begin{tabular}{cccccc}
\hline Year & $\begin{array}{c}\text { Pre-tax and } \\
\text { transfer }\end{array}$ & Official & $\begin{array}{c}\text { After tax and } \\
\text { in-kind } \\
\text { transfers }\end{array}$ & $\begin{array}{c}\text { Percent } \\
\text { Reduction } \\
(\%)\end{array}$ & $\begin{array}{c}\text { Percent } \\
\text { Reduction } \\
(\%)\end{array}$ \\
\hline 1999 & 54.8 & $(2)$ & $(3)$ & $(2) \div(1)$ & $(3) \div(2)$ \\
2000 & 54.5 & 32.3 & 26.7 & -41 & -17 \\
2001 & 56.4 & 32.9 & 27.0 & -42 & -14 \\
2002 & 59.9 & 34.6 & 27.8 & -42 & -15 \\
2003 & 61.3 & 35.9 & 29.0 & -42 & -16 \\
2004 & 62.8 & 37.0 & 30.2 & -41 & -16 \\
2005 & 61.9 & 36.9 & 30.9 & -41 & -16 \\
2006 & 61.1 & 36.5 & 30.5 & -40 & -16 \\
2007 & 62.4 & 37.3 & 31.0 & -40 & -16 \\
2008 & 66.9 & 39.8 & 33.8 & -40 & -17 \\
2009 & 74.8 & 43.5 & 35.1 & -42 & -15 \\
\hline
\end{tabular}


Table 3. Trends in Aggregate Poverty Gaps

\begin{tabular}{cccccc}
\hline Year & $\begin{array}{c}\text { Pre-tax and } \\
\text { transfer }\end{array}$ & Official & $\begin{array}{c}\text { After tax and } \\
\text { in-kind } \\
\text { transfers }\end{array}$ & $\begin{array}{c}\text { Percent } \\
\text { Reduction } \\
(\%)\end{array}$ & $\begin{array}{c}\text { Percent } \\
\text { Reduction } \\
(\%)\end{array}$ \\
\hline 1999 & 261 & $(2)$ & $(3)$ & $(2) \div(1)$ & $(3) \div(2)$ \\
\hline 2000 & 270 & 102 & 84 & -61 & -18 \\
2001 & 288 & 112 & 90 & -62 & -14 \\
2002 & 308 & 119 & 101 & -61 & -16 \\
2003 & 321 & 127 & 106 & -61 & -15 \\
2004 & 324 & 130 & 110 & -60 & -16 \\
2005 & 324 & 132 & 111 & -60 & -16 \\
2006 & 314 & 129 & 108 & -59 & -16 \\
2007 & 323 & 129 & 108 & -59 & -16 \\
2008 & 347 & 141 & 116 & -60 & -16 \\
2009 & 385 & 155 & 125 & -60 & -17 \\
\hline
\end{tabular}

Note: Billions of $\$ 2010$ 


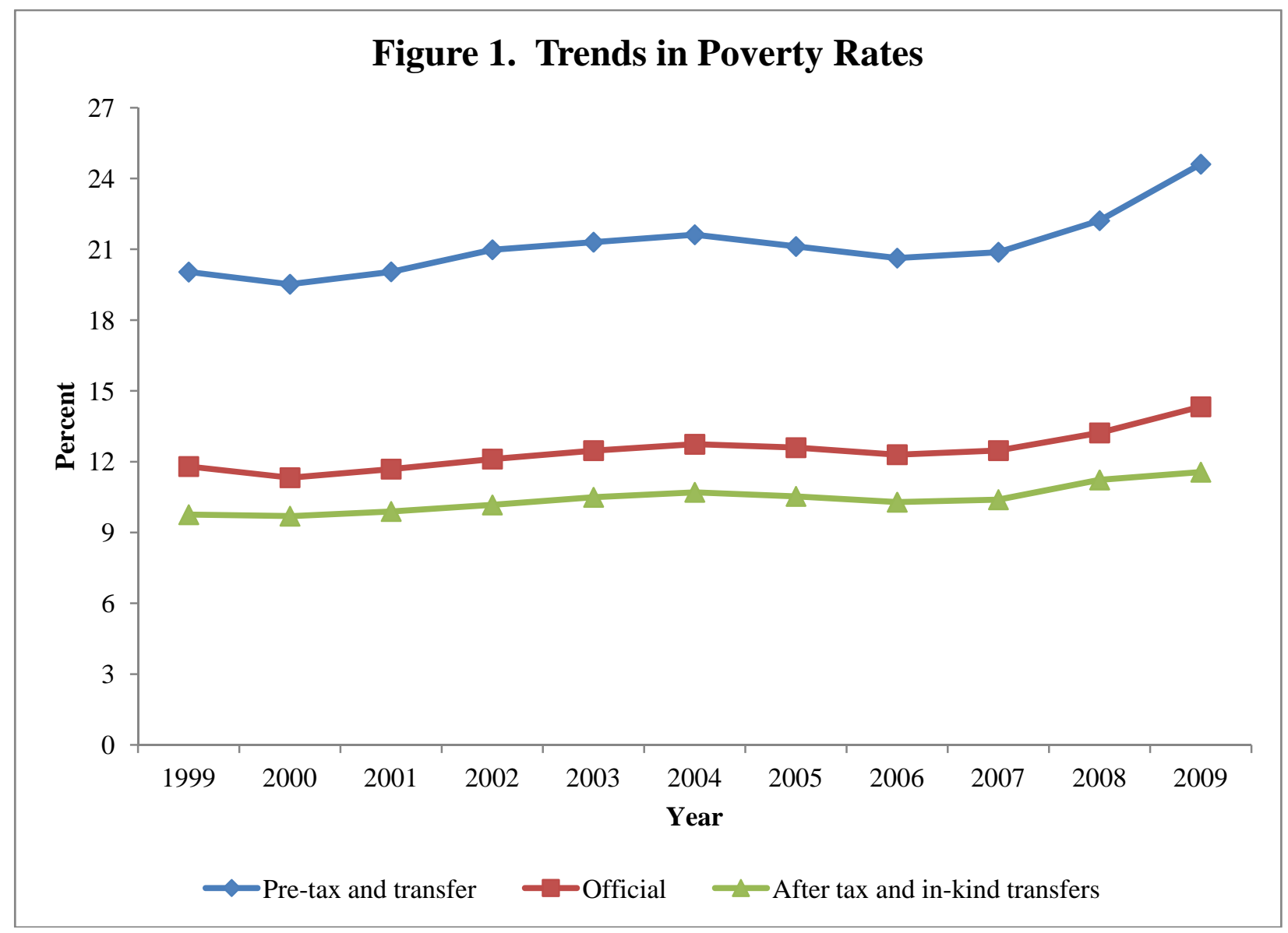




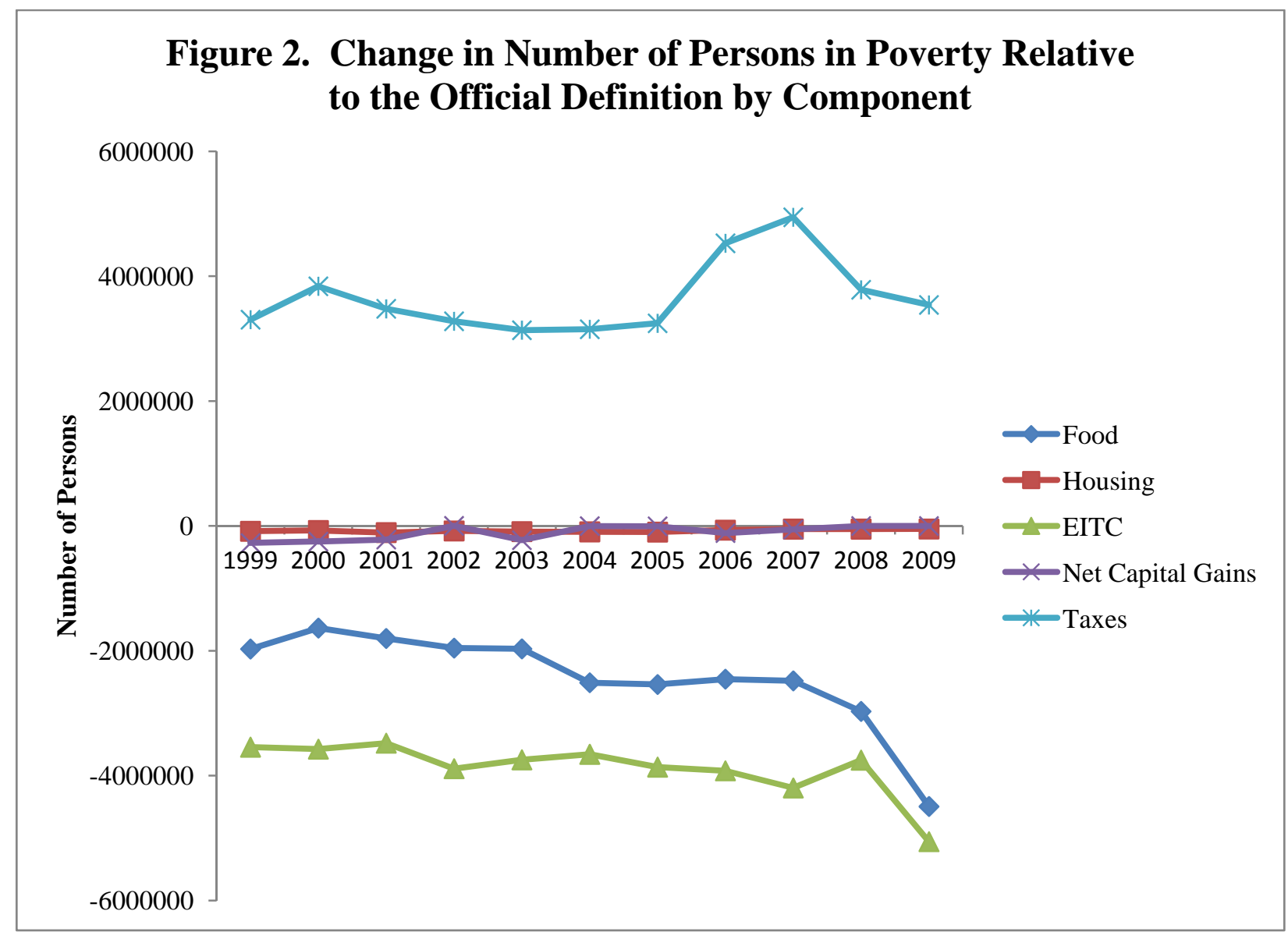




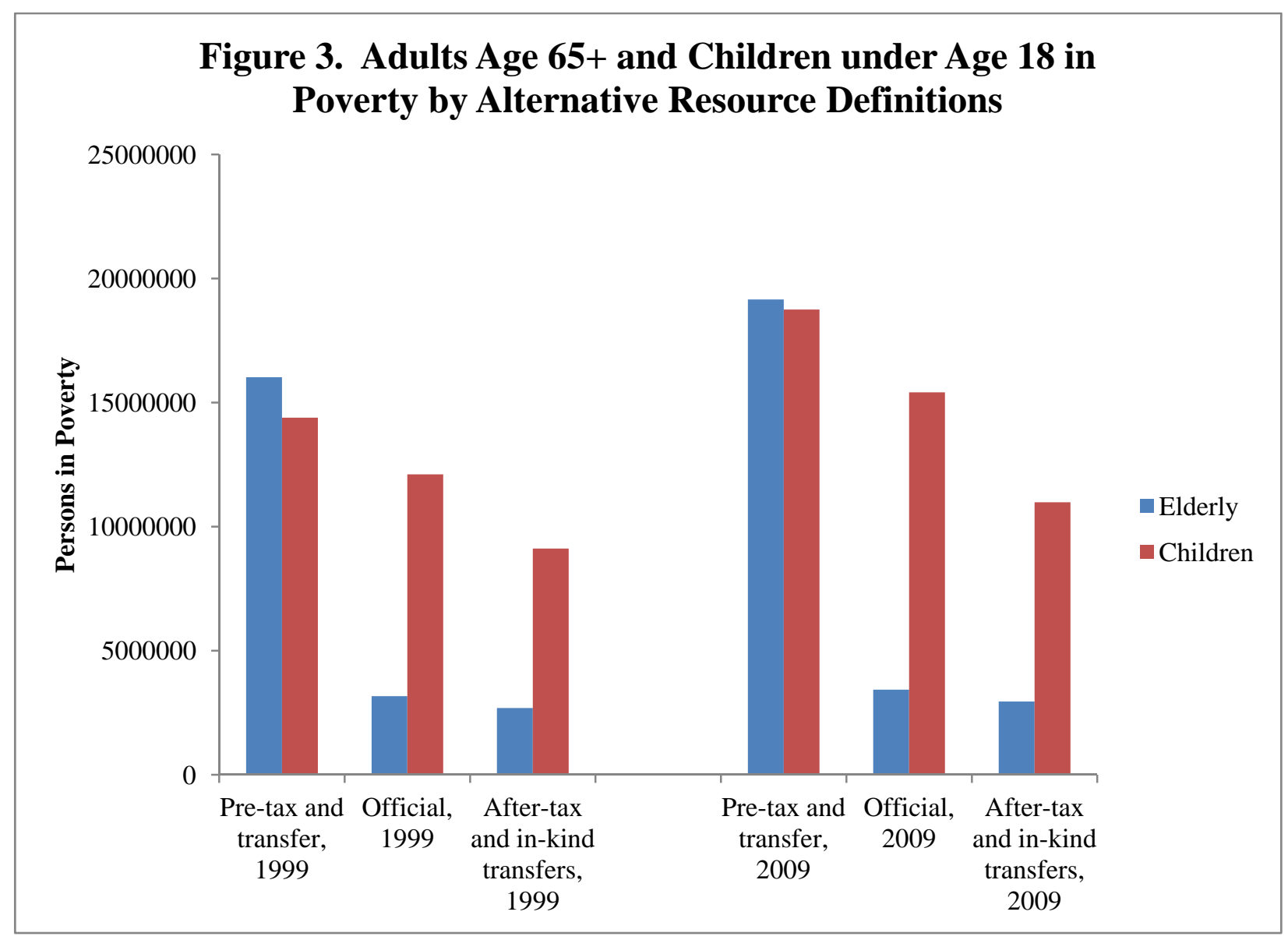




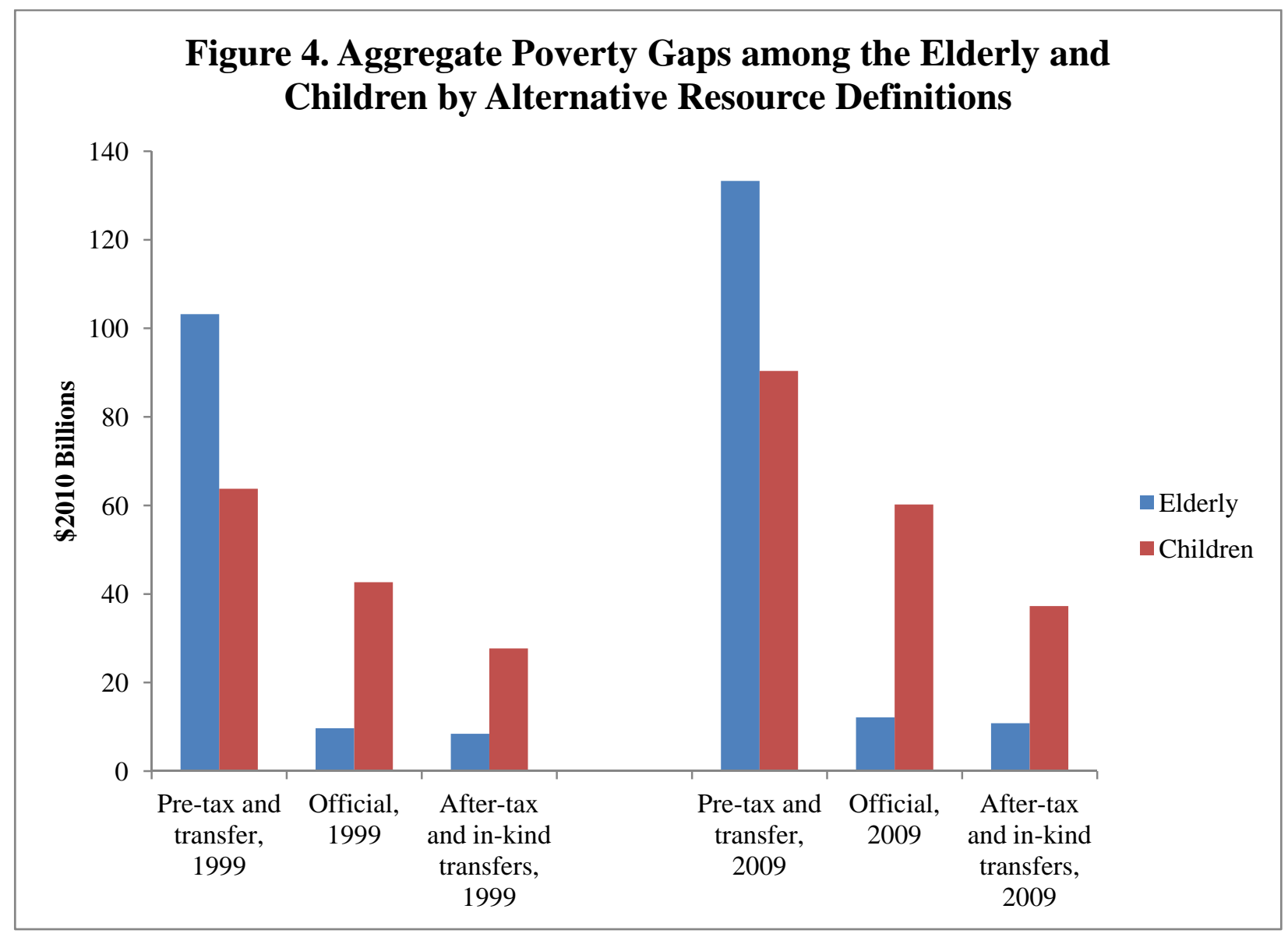




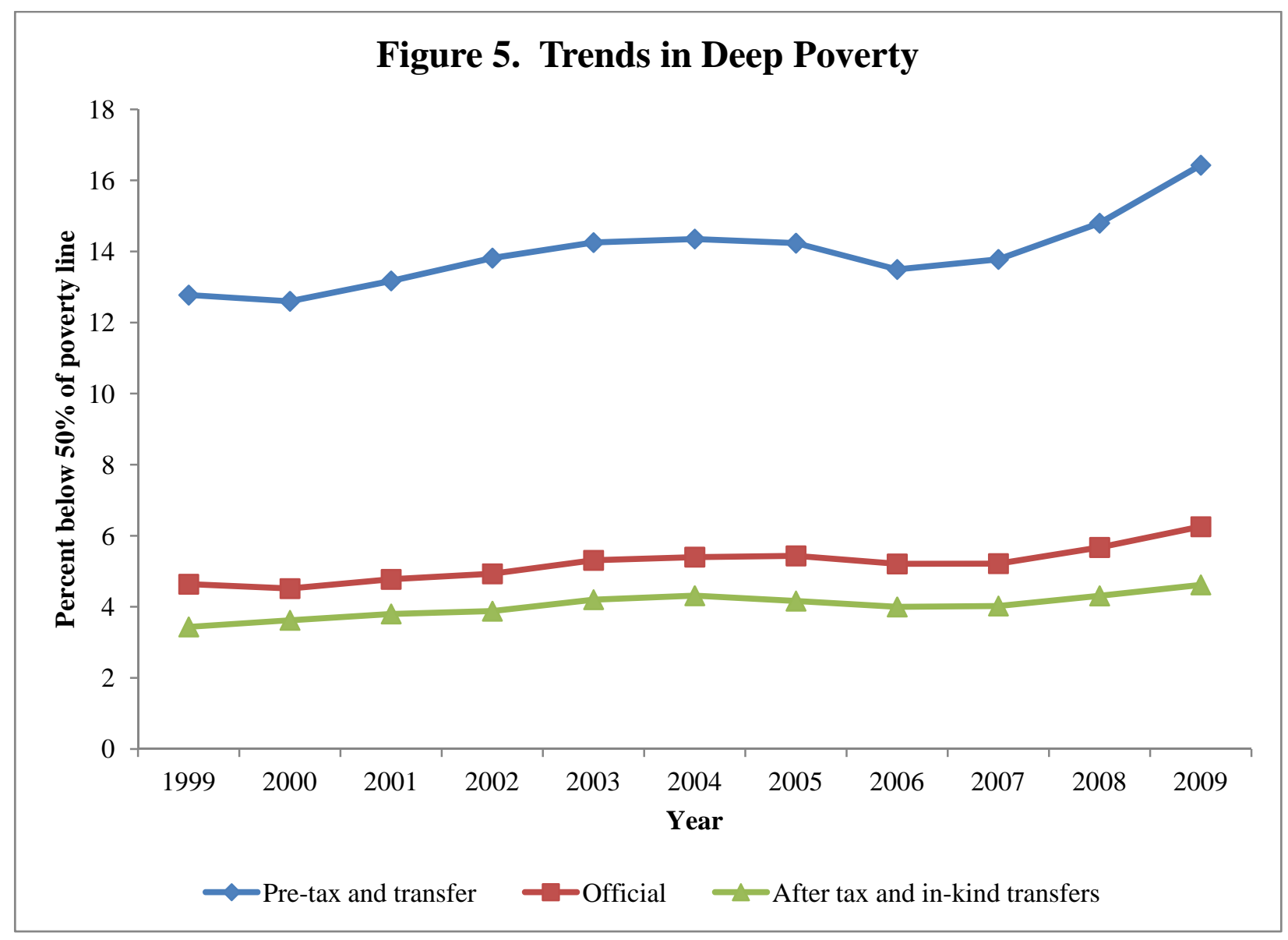




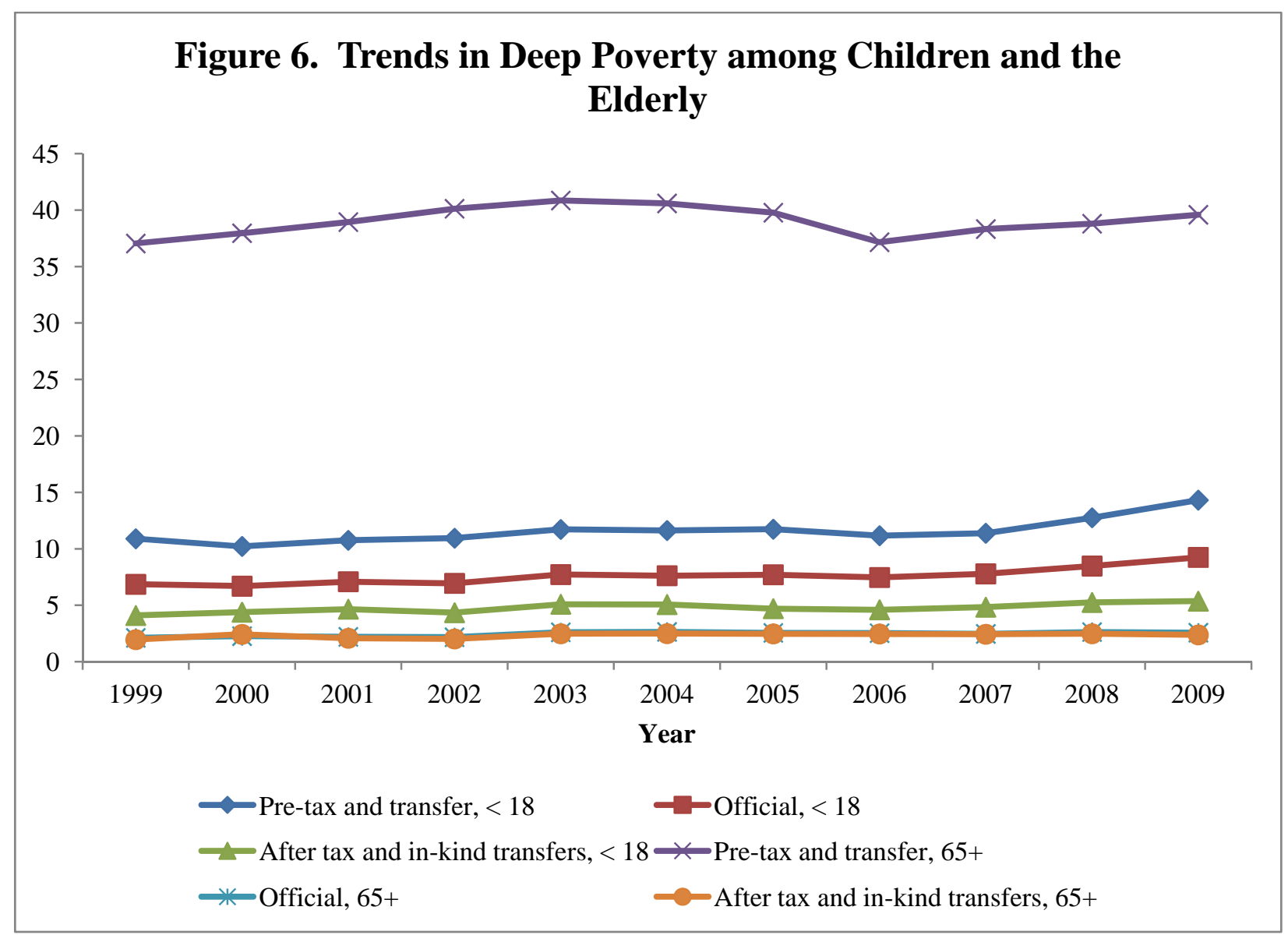




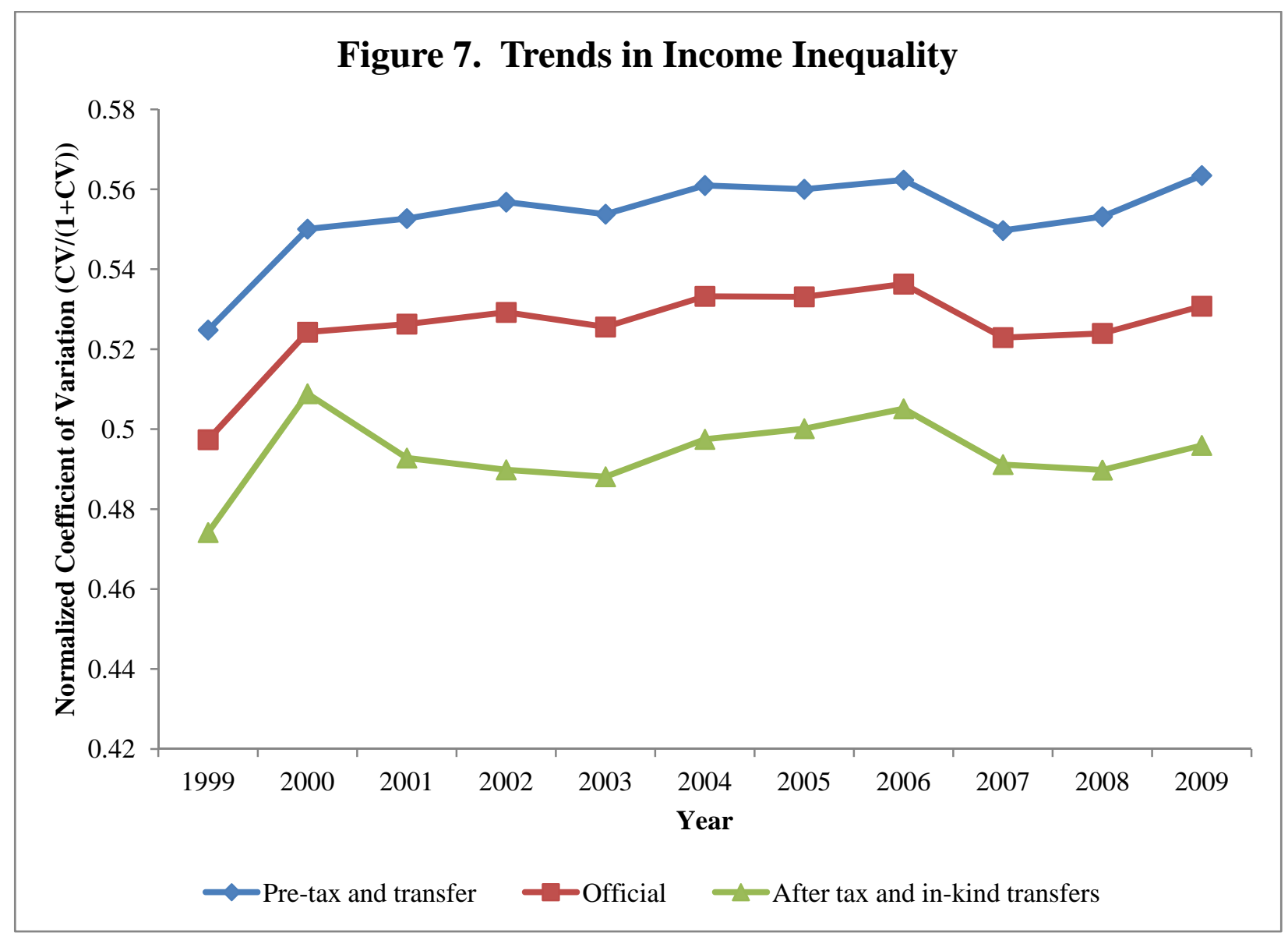




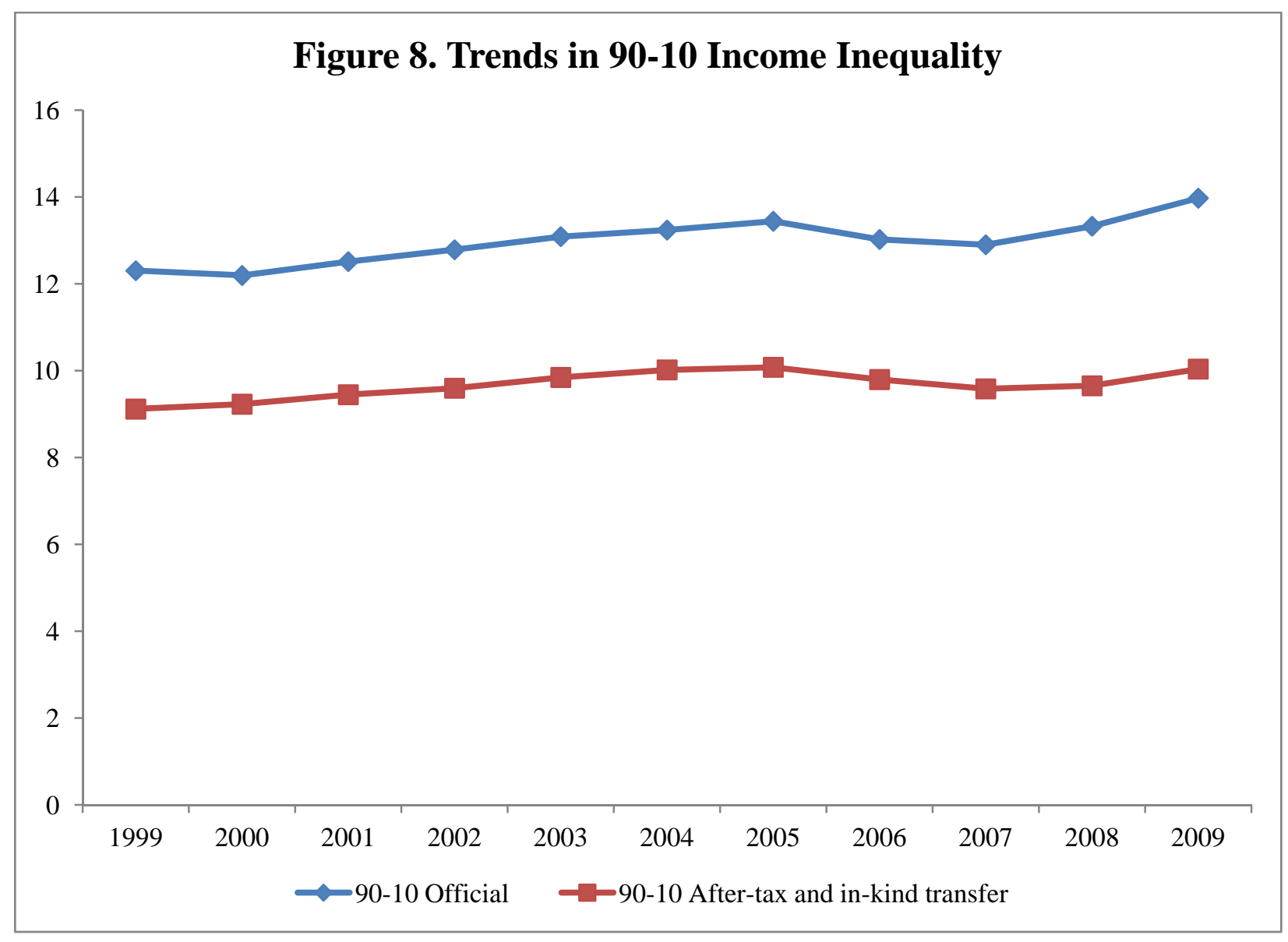




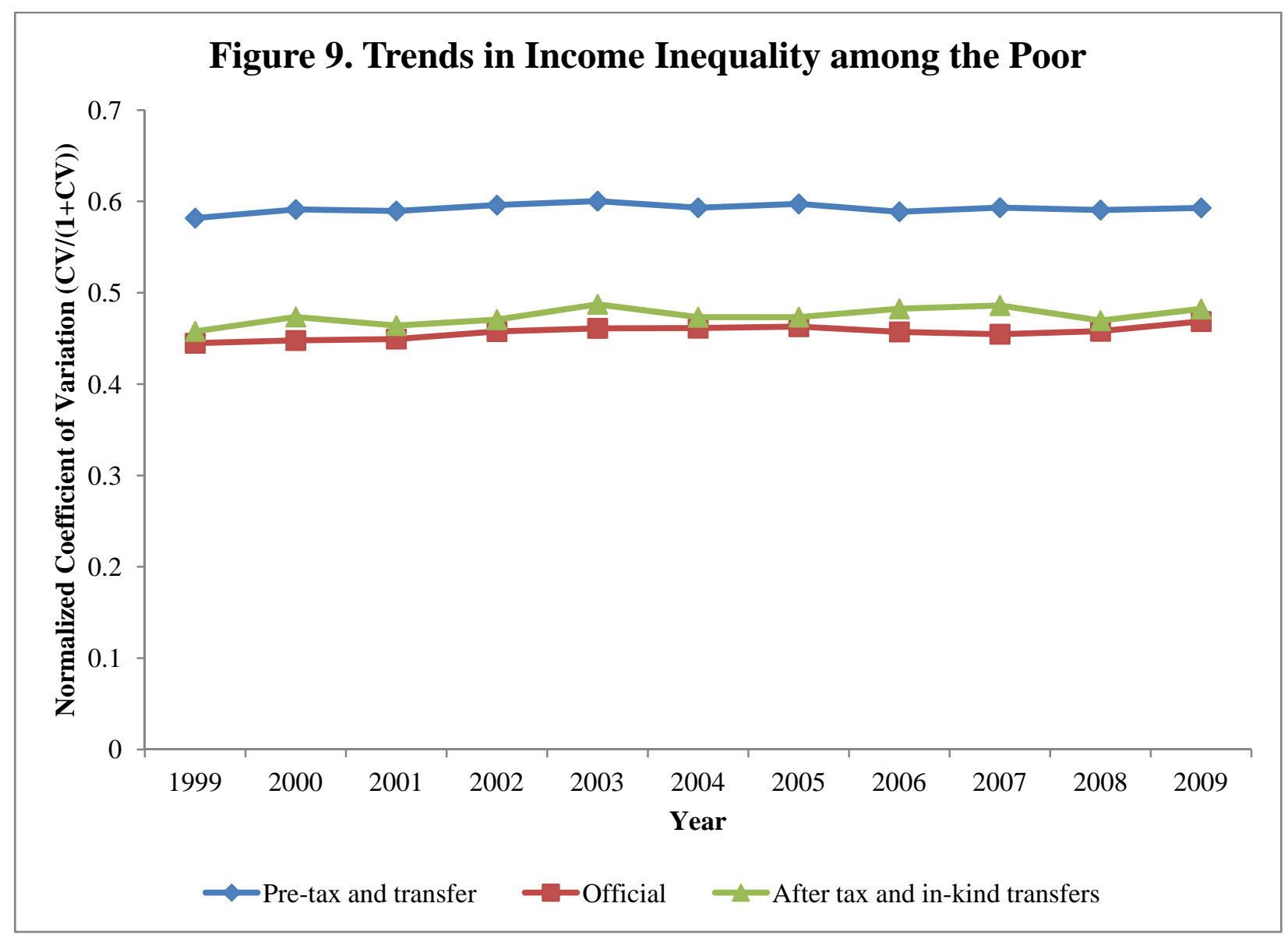




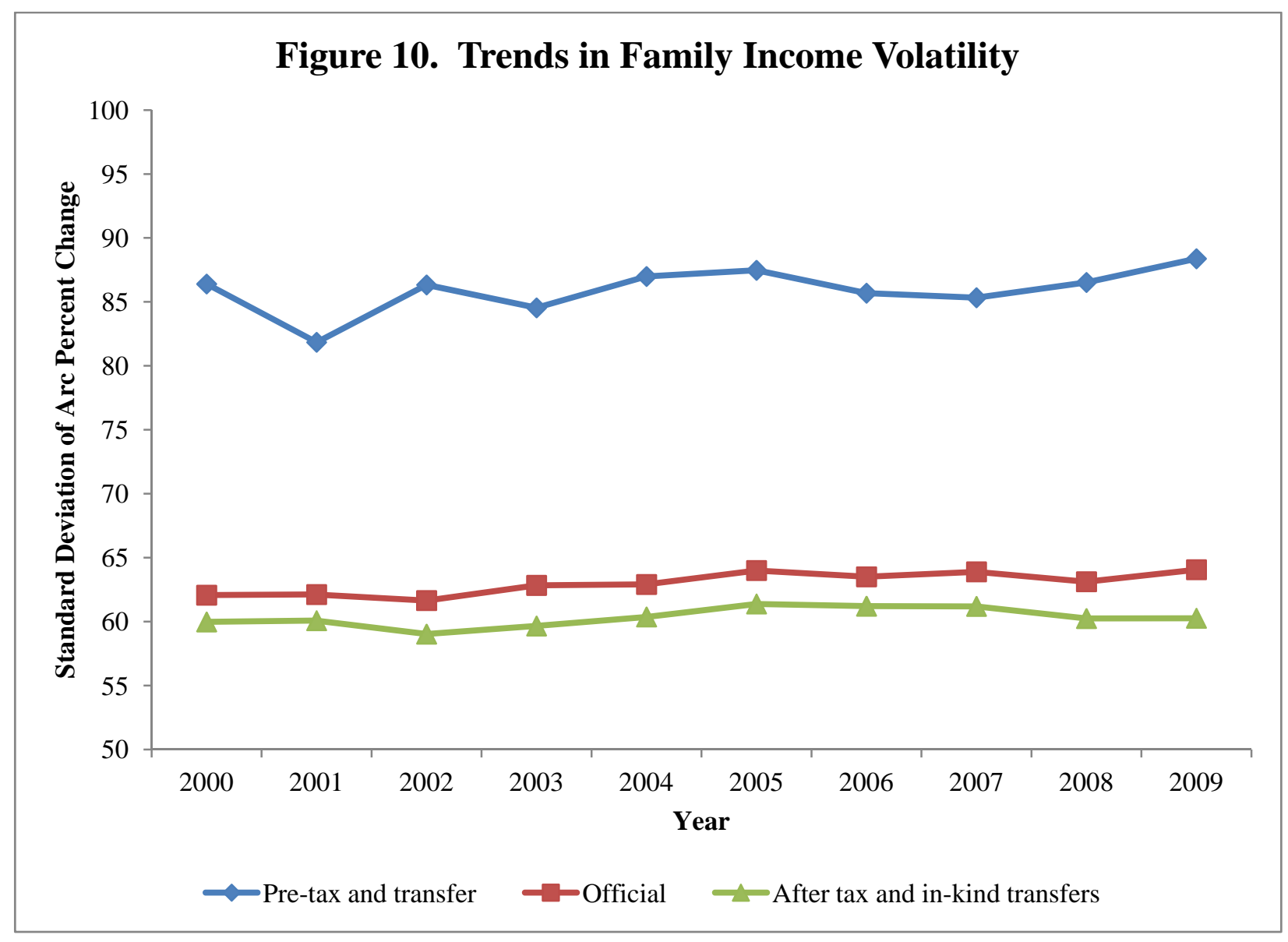




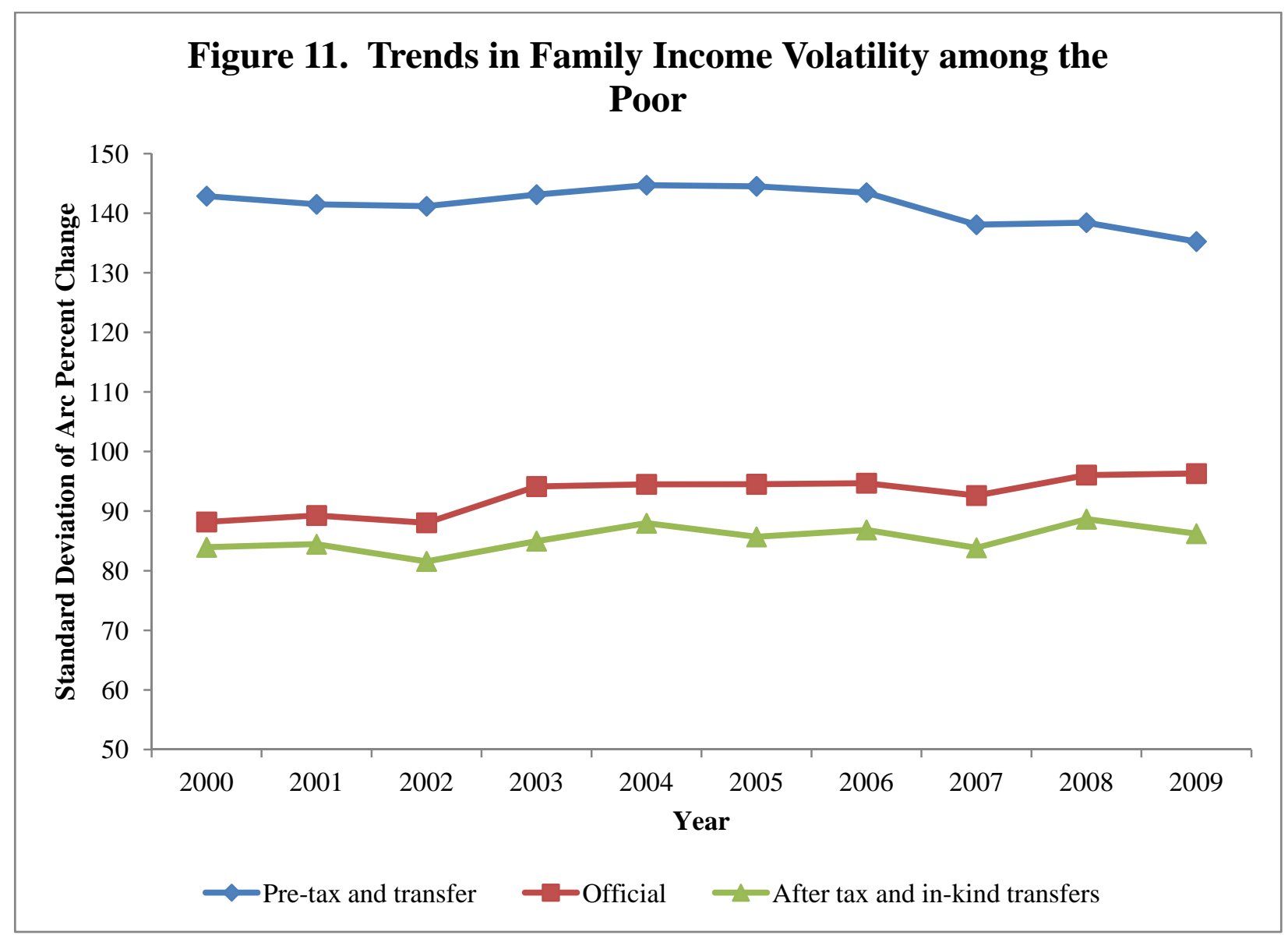

